\title{
Bringing teaching back in: The Norwegian NOU The school of the future in light of the Allgemeine Didaktik theory of Wolfgang Klafki
}

\author{
Ilmi Willbergh , \\ Department of Education, University of Agder, Norway
}

\begin{abstract}
This paper investigates the epistemology in the Norwegian NOU report, entitled The school of the future (2015), in light of the general didactic theory of Wolfgang Klafki. Klafki's concepts of material-, formal- and categorical Bildung are used to analyse the ideas of connecting knowledge and learning in the NOU report's vision of the curriculum. The paper finds that the report subordinates content knowledge to competences, creating a risk of the dominance of formal aspects of Bildung, which can devalue knowledge. The paper suggests 'bringing teaching back in': to construct a content-based curriculum with an epistemology compatible with teaching practice and to look to general didactic theory and research to accomplish this aim.
\end{abstract}

Keywords: Curriculum; epistemology; knowledge; schooling; Bildung

Received: January 2016; Accepted: October 2016; Published: December 2016

\section{Introduction}

The Norwegian Official Report The school of the future. Renewal of subjects and competences (NOU, 2015b, p. 12) argues that in the forthcoming renewal of the Norwegian curriculum, the renewal of the subject content should be based on pedagogic, didactic and pedagogical content knowledge research. The NOU suggests a competence-based curriculum in line with the international policy-wave of the 'knowledge society' (Anderson, 2008; Voogt, 2012; European Commission, 2008; European Parliament, 2007; OECD, 2005, 2007, 2012) and the Norwegian educational policy in force: the Knowledge Promotion Reform (St. Meld. Nr. 30 (2003-2004)) and the Norwegian Qualification Framework for Life-Long Learning (Kunnskapsdepartementet, 2011).

The issue of knowledge in schooling is currently debated in relation to the work of Michael Young (Young, 2008, 2013a) and represented by two special issues of two international journals: Creating curricula: aims, knowledge, and control

Correspondence: University of Agder, Service box 422, NO-4604 Kristiansand, Norway. Email: ilmi.willbergh@uia.no 
(The Curriculum Journal) (Wyse, Hayward, Livingston \& Higgins, 2014) and Michael Young, knowledge and curriculum: an international dialogue (Journal of Curriculum Studies) (Deng, 2015b). Michael Young argues that the field of curriculum theory is in a state of crisis due to the neglect of knowledge by Anglophone theorists in the post-war period (Young, 2008, 2013a, b, 2014; Young \& Muller, $2010,2013)$. This neglect stems from a blurring of different academic subjects, of academic and vocational qualifications, and of academic and everyday knowledge (Young \& Muller, 2010). The result is a devaluation of academic knowledge and traditional school subjects, to the advantage of the stipulation of curricular content in generic terms, usually skill- or outcome (Young \& Muller, 2010). Reformulations of knowledge as skills, outcomes or competences can lead to elitism, as the high culturation of the elites is hidden as individual 'talent' and 'abilities' (Beck, 2013). Young and collegues, the advocates of the concept of 'powerful knowledge', argue that academic school subjects should be prominent in school curricula, making students able to generalise beyond their experience as a result of engaging with the concepts of disciplinary knowledge (Deng, 2015b; Wyse et al., 2014).

The aim of this paper is to present an alternative perspective on this challenge of 'powerful knowledge', namely the theory of categorical Bildung by Wolfgang Klafki (1927-). The paper applies Klafki's theory in an analysis of the epistemology of the Norwegian NOU report, entitled The school of the future, investigating the following research question: What is the view of the connection between knowledge and learning in the report, and what possible consequences can this have for schooling? The analysis is followed by a brief discussion of Klafki's perspectives in relation to the challenge of 'powerful knowledge' and the White Paper that followed up the NOU (Meld. St. 28 (2015-2016)).

\section{The relation knowledge-learning in the theory of categorical Bildung}

The general didactic theory of Wolfgang Klafki is a contemporary pedagogic theory that includes a knowledge aspect and a learning aspect (Klafki, 2000a, b, 2001a, b). General didactics, 'Allgemeine Didaktik' and Bildung theories, being German and Northern-European educational theories, are relatively unknown in the English-speaking world, but interest in it has been growing since the turn of the millennium (Aasebø, Midtsundstad \& Willbergh, 2015; Deng, 2015a; Gundem \& Hopmann, 1998; Hillen, Sturm \& Willbergh (Eds.), 2011; Hillen \& Aprea, 2015; Hopmann, 2007; Kim, 2013; Krüger, 2008; Menck, 2010; Meyer, 2007; Midtsundstad \& Werler, 2011; Midtsundstad \& Willbergh, 2010; Pikkarainen, 2011; Vásquez-Levy, 2002; Westbury, Hopmann \& Riquarts, 2000; Willbergh, 2015, 2016).

As pointed out by Lundgren (2015) in one of the special issues mentioned in the introduction, when Young calls for students to generalise beyond their experience through engaging with curriculum content, he argues in line with a long European tradition. The basic task of education in the German and Scandinavian tradition is encompassed by the term Bildung (Herbart \& Stern, 2002; Westbury et al., 2000). 
Klafki's Bildung- and Didaktik theory includes epistemological aspects and practiceoriented concepts for use in lesson planning, where the Didaktik analysis is a key element (Deng, 2015a).

Klafki's view of knowledge is explained by the term categorical Bildung (Klafki, 2000a, 2001a, b). The development of this concept was a result of an analysis of the views of knowledge and learning over 150 years of educational theory, published for the first time in 1958 (Klafki, 2001b). Klafki finds that the views of knowledge and learning can be divided into two groups: material and formal Bildung theories.

\section{Material Bildung theories}

The first group comprises the theories that prioritise content over student, the objective side over the subjective side of learning, which he calls material Bildung theories. The material theories can then be divided roughly into two sub-groups: objectivism and classical Bildung. Objectivism is characterised by the belief in the objectivity of knowledge, i.e. epistemologic positivism, finding its historical roots in the teaching practices of memorising, reciting, reproducing and drilling.

Classical Bildung also prioritises content over student, but in this case the reason is not scientific objectivity, but cultural quality: Classical Bildung means that the cultural works of an ethnic group or class dominate the curriculum, where a tradition considered especially valuable is transferred from one generation to the next (Klafki, 2001b). Hence, in material Bildung-theories, the knowledge-learning-connection is dominated by the knowledge-aspect at the expense of the learning subject.

Current curricula have traits of these forms of material Bildung, for legitimate reasons. What Klafki warns of, however, is allowing the material side to dominate without considering the subjective aspects of learning. The problem of material theories is that they can become dogmatic and elitist (Klafki, 2001b; Willbergh, 2015): Epistemologic positivism can obstruct critical thinking. Classical Bildung is per definition elitist as the definition of quality is defined by elites, and additionally it is in danger of becoming irrelevant to large groups of the population. The problems of material Bildung point out the need for curricula to be revised in tune with societal developments, to ask the question of scientific and cultural value in relation to current societal context (Klafki, 2001b). After all, research and art are constantly evolving knowledge domains, and curriculum making is a matter of choosing content, a choice that cannot be decided from the material side of knowledge learning alone, but must be legitimised pedagogically by relating to today's society and the responsibility of educating children in this historic context.

\section{Formal Bildung theories}

The second group of educational theories' views on knowledge and learning are the theories that prioritise the student over knowledge, the subjective side over the objective. Klafki calls these theories formal Bildung theories (Klafki, 2001b). The sub-groups of formal Bildung theories are functional Bildung and methods-based Bildung. Functional Bildung is when the core of the curriculum is comprised by human powers, potentials, talents and abilities. Functional Bildung has its 


\section{Ilmi Willbergh}

epistemological roots in the philosophy of Rousseau - the humanist theory of the founding father of German universities, Wilhelm von Humboldt, as well as modern psychology (Weinert, 2001). The basic idea of functional Bildung is that the powers and abilities of humans are analogues to biological powers, that we are organisms with 'spiritual powers' lying slumbering waiting to be awakened. This heritage is visible in the ideas of progressive pedagogy.

Methods-based Bildung, on the other hand, argues that the subjective side of knowledge-learning should be addressed by focusing on the process of learning methods, ways of thinking, using tools and strategies to 'master life'. Methods-based Bildung is inherent in the subject-oriented ideas of 'learning to learn', 'learning strategies', e-learning and different kinds of literacies. The idea of the active learner and the theories of John Dewey are further connected to this line of thinking on knowledge-learning (Klafki, 2001b).

The functional theories are necessary components of Bildung and curricula, but they cannot stand on their own. The problem of formal Bildung theories is mainly that they remain hypothetical if they are not applied in relation to some kind of content (Klafki, 2001b). When it comes to functional Bildung, psychologists still have no comprehensive theory of human powers and abilities (Weinert, 2001). These abilities can only be observed when they are expressed and acted upon in relation to 'something' outside the person, in the world. From a curriculum-making perspective, the drive to reveal the 'hidden inner life' of humans threatens to take attention away from the important question of what children should learn in school, as well as away from the practical interaction of teacher and students in classrooms (Standish, 2012; Willbergh, 2015). Moreover, curricula focused on functional Bildung raises the question: How can a teacher motivate students to develop powers without engaging in specific content (Klafki, 2001b)? And further, how can this epistemology be legitimised when children display mastery in an ability, for example 'critical thinking' or 'creativity', in the subject of Norwegian but not in math? Furthermore, how should sub-abilities be constructed when they are in fact hypothetical and not valid from a psychological point of view (Weinert, 2001)? The 'selecting' and formulating abilities becomes an immense problem for curriculum makers. This can be seen in the tendency to come up with new competences to cover new societal challenges, such as 'digital competence' and 'social competence'.

With respect to methods-based Bildung, there are no universal methods through which the subject can grasp and process all kinds of knowledge, and claiming to do so means becoming dogmatic. The epistemology of methods-based Bildung results in problems when implementing the curricula: For methods to be universal they become too abstract to be relevant when working with specific content (Klafki, 2001b). This is exactly the challenge presented by contemporary key competences in curricula (Weinert, 2001). The abstractness of key competences leads to the creation of content-specific competences and at this point the meaning of competences is lost and the curriculum turns into a content-based curriculum (Willbergh, 2015). 


\section{Categorical Bildung}

Due to the reasons accounted for above, material and formal theories of Bildung have not succeeded in theoretically describing the 'essence' of Bildung, the connection between knowledge and learning (Klafki, 2001b). Without theoretically explaining this epistemology, such curricula will fail when implemented. The essence of Bildung is a dialectical unity with an objective and a subjective side to it, and not a synthesis of material and formal ideas mixed together. This unity is explained by the concepts of the elemental and the fundamental, which were key parts of the German Didaktik discourse in 1958 (Westbury et al., 2000). The elemental are disciplinary concepts that are so basic, so essential and so broad (categories) that they serve to encompass a whole range of phenomena in the world. But to acquire the elemental, the subject must also develop categories, and these categories are fundamental in the way they change the individuals' perspective on the world, the students' preunderstanding. When I write perspective on 'the' world here, this is not entirely correct: It is rather a question of changing the perspective on 'their' world, meaning that disciplinary knowledge must be reinterpreted according to the specific social and historical situation (Klafki, 2001b). On the curricular level this is a question of selecting relevant disciplinary knowledge, and on the teaching level it is a matter of reinterpreting knowledge in a way that can open the possibility of the specific students in class to experience it as meaningful: that they can use it to understand their world. Categorical Bildung can consequently be described metaphorically as a 'double unlocking': the knowledge is unlocked and the student is unlocked. What is essential here is that both the elemental and the fundamental are aspects of content applied in teaching practice: The elemental is content prepared for children in teaching, conceptualised by an adult. The fundamental is content brought into function in teaching, what the child does with it and how his or her perception of things is changed (Krüger, 2008). Consequently, the connection knowledge-learning inherent in the concept of Categorical Bildung is the link between the basic concepts of the school disciplines and the learning of unique students in their unique contexts. The strength of the theory is its compatibility with teaching practice. It is a contentbased theory of knowledge-learning, and not a psychological one.

The theory of categorical Bildung has consequences for the macro aspects of the educational system (mainly fitted for elementary and secondary schooling) and for the micro aspects of teaching in classrooms. On the macro level of curriculum making this means a critical editing of contemporary disciplinary knowledge in search of the elemental, using basic concepts that can serve to open the students to understanding the major challenges in contemporary society and formulating these as key questions of our time (Klafki, 2001a). Curriculum making is a normative effort and Klafki points out that these key questions must be revised and debated along with the ultimate goals of education, emancipation for all, formulated as the development of self-determination, co-determination and solidarity (Aasebø et al., 2015; Deng, 2015a; Klafki, 2000b, 2001a; Willbergh, 2015). 


\section{Ilmi Willbergh}

On the teaching-in-classrooms level, exemplary teaching represents the practical implementation of the epistemology of categorical Bildung, and the tool available to teachers is the Didaktik analysis (Klafki, 2000a). Examples are per definition something specific that represents something general, in this case general knowledge represented by a specific aesthetic object, a case, a verbal expression, a picture or the like (Wagenschein, 2000; Willbergh, 2010). The value of the use of examples in teaching is that examples can be taken from the world of the students: the elemental can become fundamental by connecting it to the familiar (Willbergh, 2016). Hence, to unlock the educational substance of a given content in the curriculum (Deng, 2015a), to teach in a way that can turn the matter (Bildungsinhalt) into meaning (Bildungsgehalt) for the students (Hopmann, 2007), the teacher analyses the content. Didaktik analysis consists of five questions (in the original version, (Klafki, 2000a)) revealing the appropriate exemplary meaning the content can illustrate, what aspect of the world the content can unlock for the students, connecting it to the subjective viewpoints of her/his students and selected aesthetic objects (Willbergh, 2016).

\section{NOU report: The school of the future}

An Official Norwegian Report is the preparatory groundwork for legislation which is often referred to in White Papers. A NOU report is not a curriculum, but the report gives advice for curriculum revision. The Committee's mandate was to assess the subjects in primary and secondary education and training in accordance with the requirements for competence in the future society and its working life (NOU, 2015b, p. 15). The members of the Committee were academic professors in the field of education, as well as persons with other occupations.

The NOU report's recommendations for future curriculum making centre on 'a broad concept of competence' that should be implemented through 'areas of competence' as the main pillar (NOU, 2015b, p. 39):

The following areas of competence (Nor. 'kompetanseområder') should serve as the foundation for a future renewal of the subjects in school:

1. subject-specific competence (Nor. 'fagområder') (in 'mathematics, natural science and technology', 'languages', 'social studies and ethics', and 'practical and aesthetic subjects')

2. competence in learning (metacognition and self-regulated learning)

3. competence in communicating, interacting and participating (reading, writing and verbal competences, collaboration, participation and democratic competence)

4. competence in exploring and creating (creativity, innovation, critical thinking and problem-solving)

Furthermore, today's basic skills in reading, writing, spoken language, numeracy and digital skills should be reformulated as competences. Digital skills should be connected more closely to subject-specific competence as well as to cross-curricula 
competences (NOU, 2015b, p. 39). The subject-specific competences (Nor. fagområder) described above are also designated as 'disciplines' in the report, and emerge as a broader content category than the separate subjects. These 'disciplines' are key to developing the curriculum, as it is in these categories that curriculum making should start, according to the Committee (NOU, 2015b, p. 48). The curriculum should have fewer and more uniformly designed objectives for students' learning than today, closer collaboration between subject matter curricula and guidance resources, better description of the progression of students' learning, implementation of standards should be considered and a new Core Curriculum (Generell Del) should be written accordingly (NOU, 2015b, pp. 78-79).

\section{Methods}

To be able to discuss the ideas of connecting knowledge and learning, a content analysis was conducted on the description of the competences and subject matter, as well as the reasoning behind them. Chapters $2-4$ in the report were the main object of analysis, which was originally conducted on the Norwegian version of the NOU report (NOU, 2015a), and then adapted to the English version in the process of writing the paper.

The concepts of Klafki on knowledge-learning served as categories for analysis to reveal what can be seen by their application in a hermeneutic design (Alvesson \& Sköldberg, 2008, p. 330). The main categories were material, formal and categorical Bildung. The limitations of the analysis are dependent on the fact that other results would have emerged with the use of other theories. The validity of the study however, lies in the generic nature of the concepts of material and formal, and its applicability in the discourse of knowledge and schooling (Alvesson \& Sköldberg, 2008, p. 48).

\section{Findings}

The findings of the analysis of the NOU will be accounted for below and then summarized before the discussion.

\section{The importance of scientific methods}

Bearing in mind the concept of categorical Bildung; scientific methods, concepts and ways of thinking become an important aspect of the subject matter in the curriculum. These curricular aspects are emphasised in the report as generally important (p. 40) and as part of the 'disciplines' (Nor. 'fagområder') (p. 27):

If pupils learn the important scientific methods and ways of thinking, concepts, and principles in different disciplines, this may help them to understand how knowledge is changed, and how to acquire new knowledge.

In the argumentation for the area of competence 3: 'competence in communicating, interacting and participating', 'reading competence' is especially connected to 


\section{Ilmi Willbergh}

understanding of academic concepts (p. $28,30,51)$ and this is also connected to the students' horizons of understanding (p. 30-31):

Together, reading and writing are seen as important tools for expanding one's own horizon of understanding and giving knowledge and motivation to participate in different societal arenas.

Competence 4: 'competence in exploring and creating' (p. 33) and the competence 'critical thinking and problem-solving' (p. 36) are further connected to scientific methods. The NOU report argues in favour of providing in-depth understanding which pupils can transfer to other contexts (p. 40) and opening for 'liberal education' ('allmenndanning' Nor., Ger. Allgemein Bildung, translated in the English report as 'liberal education', p. 42). A Bildung-oriented reasoning is displayed in the paragraph on the societal mission of schooling (p. 42):

The subjects must be relevant in the sense that they have value for society and working life, and also are adapted to the experiences, abilities and aptitudes for pupils' learning.

Consequently, a unity of knowledge-learning, coming close to categorical Bildung, can be interpreted as an aim displayed in the report. The challenge in the report when trying to realise this aim through knowledge, is the subordination of the subject matter under the four 'areas of competence', which will be accounted for below.

\section{The precedence of competences}

At first glance, competence area 1: 'subject-specific competence' (Nor. 'fagområder') (in 'mathematics, natural science and technology', 'languages', 'social studies and ethics', and 'practical and aesthetic subjects'), gives a sense of objectivist material Bildung, emphasising the traditional, academic subject content. However, the subject content is not the most important aspect in this recommended curriculum. As mentioned above, the four 'areas of competence' is the main pillar. This is expressed as follows (p. 64):

The Committee believes that the most important consideration when the subjects are to be renewed is that the four areas of competence in Chapter 2 form the basis for making priorities and choices.

Furthermore, the subordinate character of the subject content is further expressed by the recommendation that the process of curriculum making start in the 'disciplines' (Nor. fagområder) (p. 48), which are broader categories, for example 'mathematics, natural science and technology', and not traditional with the academic subject content. A thorough revision and possible changing of subject content is recommended (p. 47). This is expressed the strongest in the NOU report in relation to 'Social studies and ethics' and 'practical and aesthetic subjects', which are encouraged to integrate and share responsibility for the four 'areas of competence' (p. 56-57).

In the perspective of categorical Bildung, curriculum making is a matter of selecting disciplinary knowledge relevant to the social and historical situation (Klafki, 2001b). 
The subject content is the starting point, but with a dialectic unity with the formal aspects in mind, i.e. the question of what insights they can unlock in the students. In the NOU report, this is presented in reverse: Competences are selected and then the subjects are responsible for preparing for them, and this preparation is to be done in cooperation with other subjects. Consequently, the knowledge-learning-connection in the NOU values the learning-aspect over the knowledge-aspect. The 'areas of competence' is the main pillar of the curriculum suggested in the NOU and they are formulated as general abilities (learning, communication, interacting, participating, exploring and creating). In light of Klafki's concepts this puts the future Norwegian curriculum in danger of resulting in the problems of functional and methods-based Bildung: Conceptions of knowledge-learning prioritising learning over knowledge are hypothetical, abstract and takes attention away from the question of what children should learn in school as well as away from the practical interaction of teacher and students in classrooms.

\section{The ambiguity of concepts}

The abstract and hypothetical nature of the NOU's conception of knowledgelearning is also visible when looking at the suggestion of how the subjects are to be integrated. The NOU report seems to blur the material and formal aspects of a curriculum when they suggest common 'building blocks' as a key to closer cooperation between the subjects (p. 49):

The Committee emphasises that the subjects' methods and ways of thinking are a particularly important part of the building blocks, including the ability to think critically and solve problems - practical and theoretical, academic problems and everyday problems.

The 'building blocks' are both a subject's methods and concepts (p. 48) - material aspects, and abilities - formal aspects. With Klafki's critique of the hypothetical and abstract nature of formal theories of Bildung in mind it is relevant to ask: How can one legitimise the hierarchical structure of four overriding 'competence areas', 'disciplines', 'cross-curricular competences' and 'building blocks'? What are the research-based grounds behind these concepts? How can we prevent the next Norwegian curriculum from becoming a formal functional model of Bildung? And how can we avoid the fallacy of methods-oriented Bildung based on abstract ideals impossible to implement in practice (Weinert, 2001; Westera, 2001; Willbergh, 2015)?

\section{A conception of teacher-professionalism ignorant of history}

In the perspective of Klafki's theory of teaching; exemplary teaching by the means of Didaktik analysis; a critical perspective of the NOU's view on teacher professionalism is also relevant (p. 68-69):

Content-oriented main areas may challenge the teacher's autonomy and professional judgement when it comes to choosing which subject matter to teach. The Committee argues that using the competence areas as structuring elements in the subject curricula will give the subject curricula a stronger competence focus as 


\section{Ilmi Willbergh}

the question to ask will then be about which subject material should be chosen to promote the desired competence.

This competence-before-content formulation is exactly the opposite of Klafki's question in Didaktik analysis: What aspects of the world can the content unlock (Klafki, 2000a)? A content-based curriculum plus the teacher's autonomy to interpret the content has been the traditional way to organise schooling in Scandinavia since the 1800s (Hopmann, 2007; Midtsundstad \& Werler, 2011). The interpretation of content is the core of a teacher's professional work. To claim that content-oriented main areas may challenge teachers' autonomy is to break with the history of Norwegian teaching (Slagstad, Korsgaard \& Løvlie, 2003). Learning is ultimately an individual and subjective experience for students and that is why teaching practice can be theorized by the concepts of matter-meaning (Hopmann, 2007). A content given in the curriculum, as disciplinary knowledge, can have an infinite number of meanings and can be exemplified, contextualized and worked with in ways that are limited only by the imagination of teachers (Willbergh, 2016). Herein lays their professional autonomy.

Further, it can be argued contrary to what the NOU claims, that the competencebased system of accountability threatens teachers' professional autonomy (Beck, 2013; Deng, 2015b; Hopmann, 2007; Mausethagen, 2013; Young \& Muller, 2010). This is one of the concerns of Young and collegues, which will be discussed briefly below.

\section{Summary}

In light of the Allgemeine Didaktik theory of Klafki, the view of the connection between knowledge and learning in the NOU report is characterised by the subordination of content knowledge to competences, creating a risk of dominance of the formal aspects of Bildung in schooling, and a drawing of attention away from questions of knowledge and teaching practice. Further, the hypothetical and abstract nature of formal theories poses a challenge of implementation into teaching.

\section{Discussion: Bringing teaching back in}

Michael Young and colleagues warns of a blurring of different knowledge domains: of different academic subjects, of academic and vocational qualifications, and of academic and everyday knowledge (Young \& Muller, 2010). This blurring is expressed by curricula stipulating knowledge in non-subject matter, generic terms, such as competences, skills and qualification frameworks (Young \& Muller, 2010). Young and colleagues are concerned that this blurring will lead to the devaluation of knowledge, and subsequent de-professionalization of teachers. But the most important warning Young gives is the danger of elitism this trend of educational policy can lead to. This new elitism does not take the form of a traditional objectivist view of knowledge and the promotion of the children of the elites, but an elitism that hides itself behind 'talents' and 'abilities' (Beck, 2013; Young \& Muller, 2010). Competence-based education can result in increased individualisation in teaching 
(Hörmann, 2011; Tanner, 2013) and thus students may blame themselves for low achievements. To this aspect (of which Young warns us), the perspectives of Klafki's can be fruitful for curriculum makers. From an epistemological point of view, both Young and Klafki are striving to reach an epistemology of schooling avoiding the pitfalls of material Bildung (epistemological objectivism, cultural elitism) and the 'other extreme': formal theories of Bildung, presently in the form of competences, skills and qualification frameworks. Klafki's perspectives can reveal an alternative epistemological explanation as to why 'talents' and 'abilities' can be a cover for elitism: It draws the attention away from the practical teaching in classrooms; the interaction between teachers and students; how they talk about and work with content knowledge (Klafki, 2001b); and over to the 'hidden inner life' of humans (Standish, 2012; Willbergh, 2015). As the 'inner life' of humans is hidden to others (and from a humanist educational perspective it should remain so, or else it would lead to loss of autonomy and repression!), the task of making the hidden visible in post-millennium competence-based education is left to the measurement of learning outcomes. However, the challenge of future schooling is to bring teaching back in, to construct a curriculum with an epistemology compatible with teaching practice. Such a curriculum would set the work of teachers at the centre, and hence insure their professional autonomy.

A future curriculum, putting teaching in the centre of attention is possible by constructing a content-based curriculum. The White Paper following up the NOU expresses a step in this direction by focusing on the 'big ideas', 'core concepts' and 'key concepts' of the subject matter disciplines (Meld. St. 28 (2015-2016), p. 34; Harlen, 2015; Meyer \& Land, 2003; Wheelahan, 2007). This priority is explained by the importance of facilitating students' 'deep learning'. 'Deep learning' is explained as students' ability to use knowledge across contexts' (Pellegrino \& Hilton, 2012). Hence, deep learning appears as another word for 'competence' (Willbergh, 2015). But what is relevant in light of the argument of this paper, is that deep learning comes with ideas of how the learning process should be conducted. Students should immerse themselves in knowledge over time, and get individual feedback and challenges (Meld. St. 28 (2015-2016), p. 33). According to Keith R. Sawyer, this is one of the main sources of the concept of deep learning in the White Paper, 'Deep learning requires that learners relate new ideas and concepts to previous knowledge and experience' (Sawyer, 2006, p. 4; Meld. St. 28 (2015-2016), p. 33). Whether this concept of deep learning can be a rapprochement to powerful knowledge as: 'students being able to generalize beyond their experience by engaging with the concepts of disciplinary knowledge' (Deng, 2015b; Wyse et al., 2014), or to categorical Bildung as 'a double unlocking of the content and the student, leading to increased understanding of their world' (Klafki, 2001b), remains to be seen.

The NOU argued that renewal of subject content in the next Norwegian curriculum should be based on pedagogic, didactic and pedagogical content knowledge research (NOU, 2015b, p. 12). I hereby challenge the curriculum makers to put the interaction of teachers and students at the centre: how they talk about and work with content knowledge in classrooms. This can be assured by constructing 
a content-based curriculum, keeping the difference between matter and meaning alive (Hopmann, 2007). I suggest bringing teaching back in: to construct a curriculum with an epistemology compatible with teaching practice and to look to general didactic and pedagogical theory and research to accomplish this aim.

\section{Biografi}

Ilmi Willbergh is an Associate Professor at the Department of Education, University of Agder. Her interests center on general didactics and classroom studies. She is editor (with S. Hillen and T. Sturm) of Challenges facing contemporary didactics: Diversity of students and the role of new media in teaching and learning (Münster: Waxmann, 2011).

\section{References}

Aasebø, T. S., Midtsundstad, J. H. \& Willbergh, I. (2015). Teaching in the age of accountability: restrained by school culture? Fournal of Curriculum Studies. doi:http://dx.doi.org/10.1080/00220272.2015.1072249

Alvesson, M. \& Sköldberg, K. (2008). Tolkning och reflektion. Vetenskapsfilosofi och kvalitativ metod. (Interpretation and reflection. The philosophy of social science and qualitative methods). Lund: Studentlitteratur.

Anderson, R. E. (2008). Implications of the information and knowledge society for education. In J. Voogt \& G. Knezek (Eds.), International handbook of information technology in primary and secondary education (pp. 5-22). New York, NY: Springer.

Beck, J. (2013). Powerful knowledge, esoteric knowledge, curriculum knowledge. Cambridge fournal of Education, 43(2), 177-193.

Deng, Z. (2015a). Content, Joseph Schwab and German Didaktik. Fournal of Curriculum Studies, 47(6), $773-786$.

Deng, Z. (2015b). Michael Young, knowledge and curriculum: an international dialogue. Fournal of Curriculum Studies, 47(6), 723-732.

Gundem, B. B. \& Hopmann, S. T. (1998). Didaktik and/or curriculum. An international dialogue. New York: Peter Lang.

European Commission. (2008). The European qualification framework (eqf). Retrieved from http://ec.Europa.Eu/ education/lifelong-learning-policy/eqf_en.Htm

European Parliament. (2007). Key competences for life-long learning: A European reference framework. Retrieved from http://ec.Europa.Eu/dgs/education_cul ture/publ/pdf/ll-learning/keycomp_en.Pdf

Harlen, W. (Red.) (2015). Working with Big Ideas of Science Education. Trieste: The Science Education Programme (SEP) of IAP.

Herbart, J. F. \& Stern, J. (2002). Allgemeine pädagogik. With an introduction by feffrey Stern. Bristol: Thoemmes.

Hillen, S., T. Sturm \& Willbergh, I. (Eds.). (2011). Challenges facing contemporary didactics: Diversity of students and the role of new media in teaching and learning. Münster: Waxmann.

Hillen, S. A. \& Aprea, C. (2015). Instrumentalism in Education - where is 'Bildung' left? Münster: Waxmann.

Hopmann, S. T. (2007). Restrained teaching: The common core of Didaktik. European Educational Research fournal, 6(2), 109-124.

Hörmann, B. (2011). Capacities in diversified classrooms. In S. Hillen, T. Sturm \& I. Willbergh (Eds.), Challenges facing contemporary didactics: Diversity of students and the role of new media in teaching and learning (pp. 43-59). Münster: Waxmann.

Kim, J.-H. (2013). Teacher action research as Bildung: An application of Gadamer's philosophical hermeneutics to teacher professional development. Fournal of Curriculum Studies, 45(3), 379.

Klafki, W. (2000a). Didaktik analysis as the core of preparation of instruction. In I. Westbury, S. T. Hopmann \& K. Riquarts (Eds.), Teaching as a reflective practice. The German didaktik tradition (pp. 139-159). Mahwah, New Jersey: Lawrence Erlbaum Associates.

Klafki, W. (2000b). The significance of classical theories of bildung for a contemporary concept of allgemeinbildung. In I. Westbury, K. Riquarts \& S. T. Hopmann (Eds.), Teaching as a reflective practice: the German didaktik tradition (pp. 85-107). Mahwah, N.J.: L. Erlbaum Associates.

Klafki, W. (2001a). Dannelsesteori og didaktik - nye studier (Bildung-theory and didactics. New studies). Århus: Forlaget Klim. 
Klafki, W. (2001b). Kategorial dannelse. Bidrag til en dannelsesteoretisk fortolkning av moderne didaktikk. (Categorical Bildung. Contributions to a Bildung-theoretical interpretation of modern didactics) In E. L. Dale (Ed.), Om utdanning - klassiske tekster (pp. 167-204). Oslo.

Krüger, R. A. (2008). The significance of the concepts 'elemental' and 'fundamental' in didactic theory and practice. Fournal of Curriculum Studies, 40(2), 215.

Kunnskapsdepartementet (2011). Norsk kvalifikasjonsrammeverk for livslang laring. (The Norwegian Qualification Framework for Life-Long Learning). Oslo: The Ministry of Education and Research.

Lundgren, U. P. (2015). What's in a name? That which we call a crisis? A commentary on Michael Young's article 'Overcoming the crisis in curriculum theory'. Fournal of Curriculum Studies, 47(6), 787-801.

Mausethagen, S. (2013). A research review of the impact of accountability policies on teachers' workplace relations. Educational Research Review, 9, 16-33.

Meld. St. 28. (2015-2016). Fag - Fordypning - Forståelse. En fornyelse av Kunnskapsløftet. (Subject matters Deep learning - Understanding. A renewal of the Knowledge Promotion.) Oslo: The Ministry of Education and Research.

Menck, P. (2010). The formation of conscience: a lost topic of Didaktik. Fournal of Curriculum Studies, 33(3), 261.

Meyer, J. \& R. Land (2003). Threshold Concepts and Troublesome Knowledge: Linkages to Ways of Thinking and Practising. In C. Rust (Red.), Improving Student Learning: Theory and Practice Ten Years On. Oxford: Oxford Centre for Staff and Learning Development.

Meyer, M. A. (2007). Didactics, Sense Making, and Educational Experience. European Educational Research Fournal (Eerj), 6(2), 161.

Midtsundstad, J. H. \& Werler, T. (2011). Didaktikk $i$ Norden. (Didactics in the Nordic coutries). Kristiansand: Portal Akademisk.

Midtsundstad, J. H. \& Willbergh, I. (2010). Didaktikk - nye teoretiske perspektiver på undervisning. (Didactics. New theoretical perspectives on teaching). Oslo: Cappelen Damm.

NOU 2015: 8 (2015a). Fremtidens skole. Fornyelse av fag og kompetanser. Oslo: Kunnskapsdepartementet.

NOU 2015: 8 (2015b). The school of the future. Renewal of subjects and competences. Oslo: The Ministry of Education and Research.

OECD (2005). Definition and selection of key competences. Executive summary. Retrieved from http://www. Deseco.Admin.Ch/bfs/deseco/en/index/02.Parsys.43469.Downloadlist.2296.Downloadfile.Tmp/2005. Dskcexecutivesummary.En.Pdf

OECD (2007). Qualifications systems: Bridges to lifelong learning. Executive summary. Retrieved from http://www.Oecd.Org/edu/skills-beyond-school/ 38465471.Pdf

OECD (2012). Better skills. Better jobs. Better lives. A strategic approach to skills policies. Retrieved from http://skills.Oecd.Org/documents/oecdskillsstrategyfinaleng.Pdf

Pellegrino, J. W. \& Hilton, M. L. (2012). Education for Life and Work: Developing Transferable Knowledge and Skills in the 21st Century. Washington D. C.: The National Academies Press.

Pikkarainen, E. (2011). The Semiotics of Education: A New Vision in an Old Landscape. Educational Philosophy and Theory, 43(10), 1135.

Sawyer, K. R. (2006). Introduction: The New Science of Learning. In K. R. Sawyer (Ed.), The Cambridge Handbook of The Learning Sciences. New York: Cambridge University Press.

Slagstad, R., Korsgaard, O. \& Løvlie, L. (2003). Dannelsens forvandlinger. Oslo: Pax.

Standish, P. (2012). 'THIS' is prodused by a brain-process'! Wittgenstein, transparency and psychology today. fournal of Philosophy of Education, 46(1), 61-72.

St. Meld. Nr. 30 (2003-2004): Kultur for lering (Culture for Learning). Oslo: The Ministry of Education and Research.

Tanner, D. (2013). Race to the top and leave the children behind. Fournal of Curriculum Studies, 45, 4-15.

Vásquez-Levy, D. (2002). Bildung-centred Didaktik: a framework for examining the educational potential of subject matter. Fournal of Curriculum Studies, 34(1), 117.

Voogt, J. (2012). A comparative analysis of international frameworks for 21 st century competences: Implications for national curriculum policies. Fournal of Curriculum Studies, 44, 299-321.

Wagenschein, M. (2000). Teaching to understand: On the concept of the Exemplary in Teaching. In I. Westbury, S. T. Hopmann \& K. Riquarts (Eds.), (Eds.), Teaching as a reflective practice. The German didaktik tradition. Mahwah, New Jersey: Lawrence Erlbaum Associates.

Weinert, F. E. (2001). Concept of competence: A conceptual clarification. In D. S. Rychen \& L. H. Salganik (Eds.), Defining and selecting key competencies (pp. 45-65). Kirkland, Wash.: Hogrefe \& Huber. 


\section{Ilmi Willbergh}

Westbury, I., Hopmann, S. T. \& Riquarts, K. (2000). Teaching as a reflective practice: the German didaktik tradition. Mahwah, N.J.: L. Erlbaum Associates.

Westera, W. (2001). Competences in education: A confusion of tongues. Fournal of Curriculum Studies, 33(1), $75-88$.

Wheelahan, L. (2007). How competency-based training locks the working class out of powerful knowledge: A modified bernsteinian analysis. British fournal of Sociology of Education, 28(15), 637-651.

Willbergh, I. (2010). Mimetisk didaktikk: Om undervisning som kunst. (Mimetic didactics. On teaching as an art form.) In J. H. Midtsundstad \& I. Willbergh (Eds.), Didaktikk - nye teoretiske perspektiver på undervisning (pp. 46-62). Oslo: Cappelen Damm.

Willbergh, I. (2015). The problems of 'competence' and alternatives from the Scandinavian perspective of Bildung. Fournal of Curriculum Studies, 47(3), 334-354. http://dx.doi.org/10.1080/00220272.2014. 1002112

Willbergh, I. (2016). The representation of reality in teaching: A 'mimetic didactic' perspective on examples in plenary talk. Scandinavian Fournal of Educational Research, http://dx.doi.org/10.1080/00313831.2016. 1172500

Wyse, D., Hayward, L., Livingston, K. \& Higgins, S. (2014). Creating curricula: aims, knowledge, and control a special edition of the Curriculum Journal. The Curriculum fournal, 25(1), 2-6.

Young, M. (2008). Bringing knowledge back in: From social constructivism to social realism in the sociology of education. London and New York: Routledge.

Young, M. (2013a). Overcoming the crisis in curriculum theory: a knowledge-based approach. Fournal of Curriculum Studies, 45(2), 101-118.

Young, M. (2013b). Powerful knowledge: an analytically useful concept or just a 'sexy sounding term'? A response to John Beck's 'Powerful knowledge, esoteric knowledge, curriculum knowledge'. Cambridge Fournal of Education, 47(2), 195-198.

Young, M. (2014). What is a curriculum and what can it do? The Curriculum fournal, 25(1), 7-13.

Young, M. \& Muller, J. (2010). Three Educational Scenarios for the Future: lessons from the sociology of knowledge. European fournal of Education, 45(1), 11-27.

Young, M. \& Muller, J. (2013). On the powers of powerful knowledge. Review of education, 1(3), 229-250. 